\title{
ETHNOPOLITICAL PROCESSES IN THE CAUCASUS: IDENTITY CONFLICT AND POLITICAL ACTIVITY OF YOUTH ${ }^{1}$
}

\author{
Aleksej M. Erohin \\ North-Caucasus Federal University, Stavropol, Russian Federation \\ Sergej M. Vorobev \\ North-Caucasus Federal University, Stavropol, Russian Federation \\ Evgenii A. Avdeev \\ North-Caucasus Federal University, Stavropol, Russian Federation
}

\begin{abstract}
Introduction. The article presents the results of the research, which helped to determine the assessments and perceptions of young people in the Caucasus region about the state, nature and direction of the development of ethnopolitical processes, to identify common and special in the views of youth in the North and South Caucasus. Methods and Materials. Sociological research within the framework of the scientific project "Ethno-Political Processes in the Caucasus in the Assessments and Perceptions of Modern Youth" was carried out by the authors of the article in 2019 using the online survey method. 2,000 respondents were interviewed, namely students of leading universities of the region (1,000 respondents were interviewed in the North Caucasus and 1,000 respondents in the South Caucasus), the age of the respondents being 18-24 years old. The role of state authorities in the formation of civic and national identity among youth of the North Caucasus was revealed as a result of the content analysis of regional programs and other information materials in 2018. Analysis. It was found that the spectrum of the main ethnopolitical issues of concern to young people in the Caucasus region is largely identical for both the North and South Caucasus. It was revealed that civic, national, and religious identities are of priority and equal importance for the vast majority of youth. Civic and national identity for the absolute majority of Caucasian respondents is associated with the preservation of national culture and history, pride of their country and its achievements, protection of the Fatherland, and the guarantee of human rights and freedoms. Regional identity is a priority for the overwhelming majority of young people in the Caucasus. It can be assumed that risks of conflict between civil, national, and confessional identities persist among young people in the region. Youth in the Caucasus have a high level of political activity and consider their active participation in the political life of the region necessary. At the same time, they are more inclined towards a constructive solution to socio-political $\vec{\delta}$ problems, volunteering, as well as dialogue and cooperation with state authorities. The main actors forming political views, according to the majority of respondents, are the environment in which they communicate, close relatives, as well as the blogosphere and social networks. The role of state administration in the formation of civil and $\approx$ national identity among young people in the North Caucasus is analyzed. The conclusion is that it is necessary to of strengthen work in the region to develop public initiatives among youth, to involve them in socially significant activities, to activate their creative potential, and to develop their participation in various civil society institutions, $\sum$ especially volunteer organizations. Results. The conclusion is made about the need for a wide integration of young

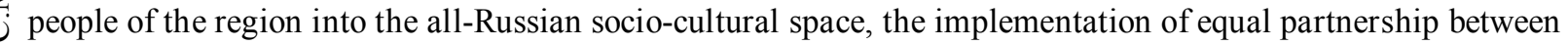
Oouth, civil society institutions and state authorities, greater involvement of young people in activities that contribute to the economic, socio-political and cultural development of the region.

Key words: youth, ethnopolitical processes, Caucasus, political activity, civic identity, national identity.

Citation. Erohin A.M., Vorobev S.M., Avdeev E.A. Ethnopolitical Processes in the Caucasus: Identity Conflict and Political Activity of Youth. Vestnik Volgogradskogo gosudarstvennogo universiteta. Seriya 4. Istoriya. Regionovedenie. Mezhdunarodnye otnosheniya [Science Journal of Volgograd State University. History. Area Studies. International Relations], 2021, vol. 26, no. 5, pp. 112-125. (in Russian). DOI: https://doi.org/10.15688/ jvolsu4.2021.5.9
\end{abstract}




\title{
ЭТНОПОЛИТИЧЕСКИЕ ПРОЦЕССЫ НА КАВКАЗЕ: КОНФЛИКТ ИДЕНТИЧНОСТЕЙ И ПОЛИТИЧЕСКАЯ АКТИВНОСТЬ МОЛОДЕЖИ ${ }^{1}$
}

\author{
Алексей Михайлович Ерохин \\ Северо-Кавказский федеральный университет, г. Ставрополь, Российская Федерация \\ Сергей Михайлович Воробьев \\ Северо-Кавказский федеральный университет, г. Ставрополь, Российская Федерация \\ Евгений Александрович Авдеев \\ Северо-Кавказский федеральный университет, г. Ставрополь, Российская Федерация
}

\begin{abstract}
Аннотация. В статье рассматриваются результаты исследования, позволившего определить оценки и представления молодежи Кавказского региона о состоянии, характере и направленности развития этнополитических процессов, выявить общее и особенное в представлениях молодежи Северного Кавказа и Южного Кавказа. Было установлено, что спектр основных этнополитических проблем, которые беспокоят молодежь Кавказского региона, во многом идентичен как для Северного Кавказа, так и для Южного Кавказа. Выявлено, что гражданская, национальная и религиозная идентичности являются приоритетными и равнозначными для абсолютного большинства молодых людей. Национальная идентичность для преобладающего числа респондентов Кавказа связана с сохранением национальной культуры и истории, гордостью за свою страну и ее достижения, защитой Отечества. Можно предположить, что среди молодежи региона сохраняются риски конфликтности гражданской, национальной и конфессиональной идентичностей. У молодых людей на Северном и Южном Кавказе выявлен высокий уровень политической активности, большинство опрошенных желает участвовать в общественно-политической жизни страны. При этом молодежь региона настроена в большей степени на конструктивное решение социально-политических проблем, волонтерскую деятельность, а также диалог и сотрудничество с органами государственной власти. Главными акторами, формирующими политические взгляды, по мнению большинства респондентов, являются среда, в которой они общаются, близкие родственники, а также блогосфера и социальные сети. Анализируется роль органов государственного управления в формировании гражданской и национальной идентичности у молодежи Северного Кавказа. Делается вывод о необходимости широкой интеграции молодежи региона в общероссийское социокультурное пространство, реализации равноправного партнерства молодежи, институтов гражданского общества и органов государственного управления, большее включение молодых людей в деятельность, способствующую экономическому, социально-политическому и культурному развитию региона. Вклад авторов. Создание концепции статьи, написание вводного раздела принадлежит А.М. Ерохину. Разработка и описание методологии исследование принадлежит С.М. Воробьеву и Е.А. Авдееву. Анализ результатов исследования конфликта идентичностей и политической активности молодежи принадлежит А.М. Ерохину, С.М. Воробьеву, Е.А. Авдееву. Оценка роли органов государственного управления в формировании гражданской и национальной идентичности у молодежи Северного Кавказа на основе контент-анализа проведена Е.А. Авдеевым. Выводы и рекомендации сформулированы С.М. Воробьевым и Е.А. Авдеевым.

Ключевые слова: молодежь, этнополитические процессы, Кавказ, политическая активность, гражданская идентичность, национальная идентичность.

Цитирование. Ерохин А. М., Воробьев С. М., Авдеев Е. А. Этнополитические процессы на Кавказе: конфликт идентичностей и политическая активность молодежи // Вестник Волгоградского государственного университета. Серия 4, История. Регионоведение. Международные отношения. - 2021. - T. 26, № 5. - C. 112-125. - DOI: https://doi.org/10.15688/jvolsu4.2021.5.9
\end{abstract}

Введение. Кавказ является значимым геостратегическим макрорегионом, сочетающим в себе сложную палитру этнополитичес- ких проблем, несущих риски и угрозы безопасности, сепаратизма и экстремизма в России. Взаимодействие Российской Федерации 
со странами Южного Кавказа является основным фактором стабилизации этнополитических процессов, укрепления интеграционных связей, мира и добрососедства в регионе. Латентная конфликтность в сфере этнополитических процессов и постоянная угроза дестабилизации этнополитического пространства региона - фундаментальная проблема, требующая научного анализа и конструктивного решения для обеспечения политической стабильности и дальнейшей экономической и социокультурной интеграции. Кавказ - полиэтничный и поликонфессиональный регион, и это обусловливает наличие рисков конфликтности в этнополитических процессах. В 2019 г. авторами статьи в рамках научного проекта «Этнополитические процессы на Кавказе в оценках и представлениях современной молодежи» (грант РФФИ № 19-011-31300) было проведено исследование оценок и представлений молодежи Кавказа о состоянии, характере и направленности развития этнополитических процессов в регионе методом социологического опроса. Контент-анализ региональных программ и других информационных материалов региональных органов публичной власти позволил изучить передовой опыт и выявить инновационные, социально значимые молодежные мероприятия, проводившиеся в регионе.

Методы и материалы. Методологической основой анализа является нормативно-ценностная концепция М. Вебера, основанная на идеях о коллективных представлениях, убеждениях, целях и ценностях, лежащих в основе идентичности [2], структурный функционализм Т. Парсонса, который позволяет рассмотреть роль политических акторов в социальных взаимодействиях [6], теория социальной коммуникации К. Дойча в аспектах роли коммуникации в формировании национальных и государственных общностей [14]. Также методологической основой выступает концепция формирования гражданской идентичности Ч. Тилли на основе укрепления устойчивой связи между индивидом и государством [19] и концепция расширения инфраструктурной власти государства М. Манна, предполагающая усиливающееся влияние государства на все сферы общественной жизни, которое замещает традиционные механиз- мы регламентации социальных отношений [15]. При этом происходит и возрастание воздействия гражданского общества на институты государственной власти. Применение подходов Ч. Тилли и М. Манна для исследования специфики взаимодействия государственной власти и гражданского общества на Кавказе теоретически обосновывается Н.Ю. Силаевым [8].

Понятие «конфликты идентичностей» было рассмотрено Дж. Бертоном и Дж. Ротманом. Согласно Дж. Бертону, базовыми для человека становятся потребности в идентичности и безопасности. Риски размывания и потери идентичности рассматриваются им как одна из главных угроз безопасности. Дж. Ротман отмечет такие важные свойства конфликта идентичностей (с трудом поддающиеся управлению), как иррациональность и субъективность [17]. По мнению Э. Смита, в основе формирования современных гражданских наций лежат этническая идентичность, этническая солидарность, культура и историческая память [18, с. 16]. При рассмотрении статуса этнической идентичности в содержании региональных конфликтов четко прослеживается связь с социокультурными ценностями традиционных обществ, при этом гражданская идентичность и индивидуалистические ценности не имеют большого значения. Участие молодежи в политической жизни важно в силу ряда причин, таких как: возможность влиять на процессы принятия решений с целью защиты групповых интересов; политическое участие предполагает развитие политической социализации, усиливает чувство личной принадлежности, что развивает гражданскую идентичность. Все это важно при урегулировании межнациональных конфликтов, развитии гражданской идентичности в полиэтничных и поликультурных сообществах.

В ходе проведенного авторами статьи в 2019 г. социологического исследования в рамках научного проекта «Этнополитические процессы на Кавказе в оценках и представлениях современной молодежи» было опрошено 2000 респондентов - студентов ведущих вузов региона (1 000 чел. на Северном и 1000 чел. на Южном Кавказе), возраст опрошенных 18-24 года. На Северном Кавказе респондентами стали студенты - представители всех 
субъектов СКФО РФ, на Южном Кавказе студенты Республик Южная Осетия, Абхазия, Армения и Азербайджан. Опрос был проведен в онлайн-форме, вопросы анкеты были сформированы с помощью облачных инструментов (Google Формы). Роль органов государственного управления в формировании гражданской и национальной идентичности у молодежи Северного Кавказа была раскрыта в результате контент-анализа региональных программ и других информационных материалов, отражающих работу органов публичной власти по формированию межнационального согласия, гражданственности и патриотизма современной молодежи субъектов СКФО РФ в 2018 году.

Анализ. На основе исследования было установлено, что этнополитические процессы на Кавказе характеризуются высокой политической активностью молодежи, в молодежной среде сохраняется риск возникновения конфликта гражданской, национальной и религиозной идентичности. Северный Кавказ проходит сложный этап модернизации и урбанизации, сопровождающийся разрушением традиционного образа жизни, снижением значения прежних общественных отношений, ведущую роль в которых играли род и община. Молодежь региона, предпочитающая городской образ жизни, ценности индивидуализма, самореализации и материального благополучия, в большей степени подвержена данным трансформациям, которые зачастую носят конфликтный характер [9]. Результаты проводившихся в Северо-Кавказском регионе социологических исследований показывают, что здесь общая государственность является определяющей формирование гражданской идентичности. Так, по словам В.А. Тишкова, общероссийская идентичность представляет собой «солидарность и повседневную лояльность, чувство принадлежности к одному народу и признание государства своим» $[11$, с. 66]. В основе формирования межнационального согласия, солидарности и укрепления социальнополитической стабильности на Северном Кавказе лежит идея «единства России как поликультурной страны и единения россиян как многонационального народа с общей историей, с тысячелетним уникальным цивилизационным ресурсом» [4, с. 11]. Гражданская идентичность является приоритетной для аб- солютного большинства россиян (по данным исследования ИС РАН, она была зафиксирована у $75 \%$ опрошенных; согласно опросам ВЦИОМ по заданию ФАДН в конце 2017 г., - у 84 \% респондентов). Как отмечает Л.М. Дробижева, «на повседневном уровне наши граждане вполне разделяют российскую, гражданскую идентичность, отделяя ее от этнической (этнонациональной)» [3, с. 107-108].

По результатам региональных исследований, проводившихся в 2017-2018 гг., можно заключить, что в СКФО сохраняются корни и конкретные источники этнополитической напряженности, что придает сформировавшемуся в последние годы позитивному тренду развития межэтнических отношений неустойчивый характер и повышает риски дестабилизации этнополитической ситуации [5; 13]. Региональными экспертами также отмечается, что в молодежной среде на Северном Кавказе продолжает сохраняться риск возникновения конфликта гражданской, этнической и религиозной идентичностей. Ксенофобия хотя и не является в современной молодежной среде преобладающей тенденцией, но иногда проявляется в бытовых взаимоотношениях и в интернет-пространстве [3; 12 , с. 10-12]. Исследование 2013 и 2014 г., проведенное группой экспертов под руководством академика В.А. Тишкова, показало, что ассоциации с образом Родины разделились практически поровну между своим регионом (56\% опрошенных) и страной в целом (51\% опрошенных) [10, с. 81-83]. Результаты исследования Института социологии РАН свидетельствуют о том, что главными чувствами, которые выражают личное отношение россиян к сегодняшней России, являются любовь, гордость и уважение [7, с. 159]. В.А. Авксентьев и Г.Д. Гриценко отмечают, что в регионе сохраняется вероятность конфликта общероссийской, этноконфессиональной и региональной идентичностей $[1$, с. 81$]$.

Молодежь в XXI в. по-прежнему характеризуется высоким уровнем политической активности, при этом процессы ее формирования и направленность деятельности во многом отличаются от предыдущих поколений. Наряду с прежними социальными институтами формирования личности молодых людей большую роль играют социальные сети и но- 
вые медиа. Цифровая среда формирует новые системы социальной коммуникации, Интернет становится альтернативой, дополняющей реальное существование молодых людей [16, с. 347]. Особенностью политического участия молодежи становится его неформальность, обращение к новым, зачастую неинституционализированным политическим практикам и инструментам [20].

Результаты. По результатам исследования «Этнополитические процессы на Кавказе в оценках и представлениях современной молодежи», проведенного в 2019 г. авторами статьи, установлено: наиболее важными для абсолютного большинства молодых людей Кавказа являются гражданская, национальная и религиозная идентичности, что может привести к конфликтности этих свойств. Религиозные нормы в большей степени являются основой поведения для студентов Северного Кавказа, а правовые нормы - Южного Кавказа. Гражданская идентичность является важной для абсолютного большинства респондентов ( $81 \%$ опрошенных на Северном и $76 \%$ на Южном Кавказе). Две трети респондентов отметили важность для себя и национальной идентичности (67\% опрошенных на Северном и $75 \%$ - на Южном Кавказе). Таким образом, в структуре идентичностей студентов как Северного, так и Южного
Кавказа одинаково приоритетными являются как национальная, так и гражданская идентичности (рис. 1).

Значимость гражданской, национальной и религиозной идентичностей проявляется и в нормах, которые являются основой поведения молодежи. Среди них выделяются правила поведения, которые приняты в их окружении, $20 \%$ на Северном и $25 \%$ на Южном Кавказе, а также традиции и обычаи народа, к которому они принадлежат, $-24 \%$ на Северном и 18 \% на Южном Кавказе. Религиозные нормы являются основой поведения для $24 \%$ студентов Северного Кавказа и $11 \%$ студентов Южного Кавказа. Правовые нормы являются основой поведения для $20 \%$ студентов Северного и 30 \% Южного Кавказа. Основой поведения студентов и Северного, и Южного Кавказа являются общие нормы, принятые в их окружении, традиции и обычаи народа, к которому они принадлежат, а также основы светской этики. Религиозные нормы более значимы для студентов Северного Кавказа, а правовые нормы - для студентов Южного Кавказа (см. рис. 2).

Абсолютное большинство опрошенных студентов Северного и Южного Кавказа считает важным для себя осознание связи со своей страной, с малой родиной, ближайшими родственниками и людьми своей национальности (см. рис. 3).

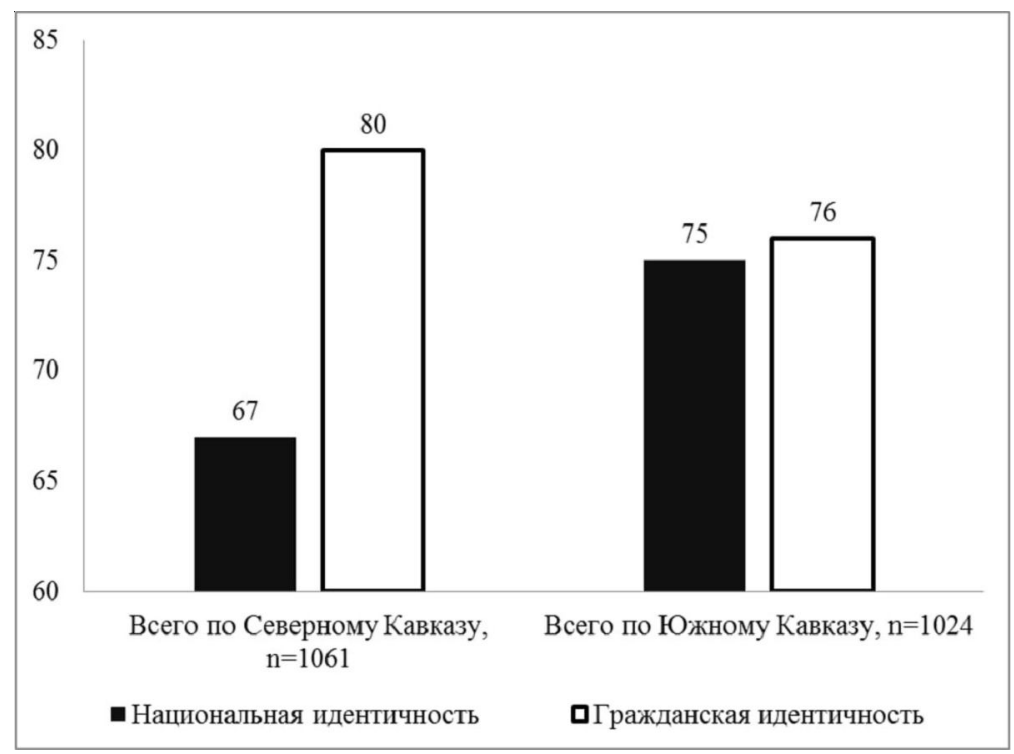

Рис. 1. Какие из идентичностей для Вас являются наиболее важными? (в \%)

Fig. 1. Which of the identities are most important to you? (\%) 
А.М. Ерохин, С.М. Воробьев, Е.А. Авдеев. Этнополитические процессы на Кавказе

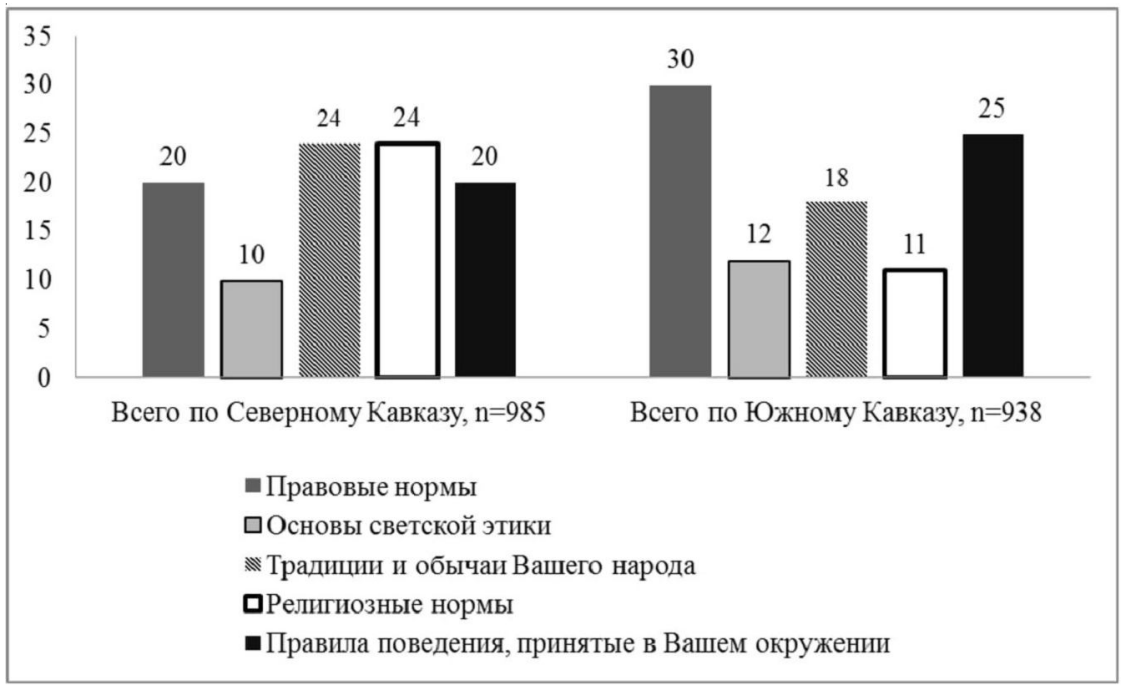

Рис. 2. Какие нормы, прежде всего, являются основой Вашего поведения? (в \%)

Fig. 2. What norms, first of all, are the basis of your behavior? (\%)

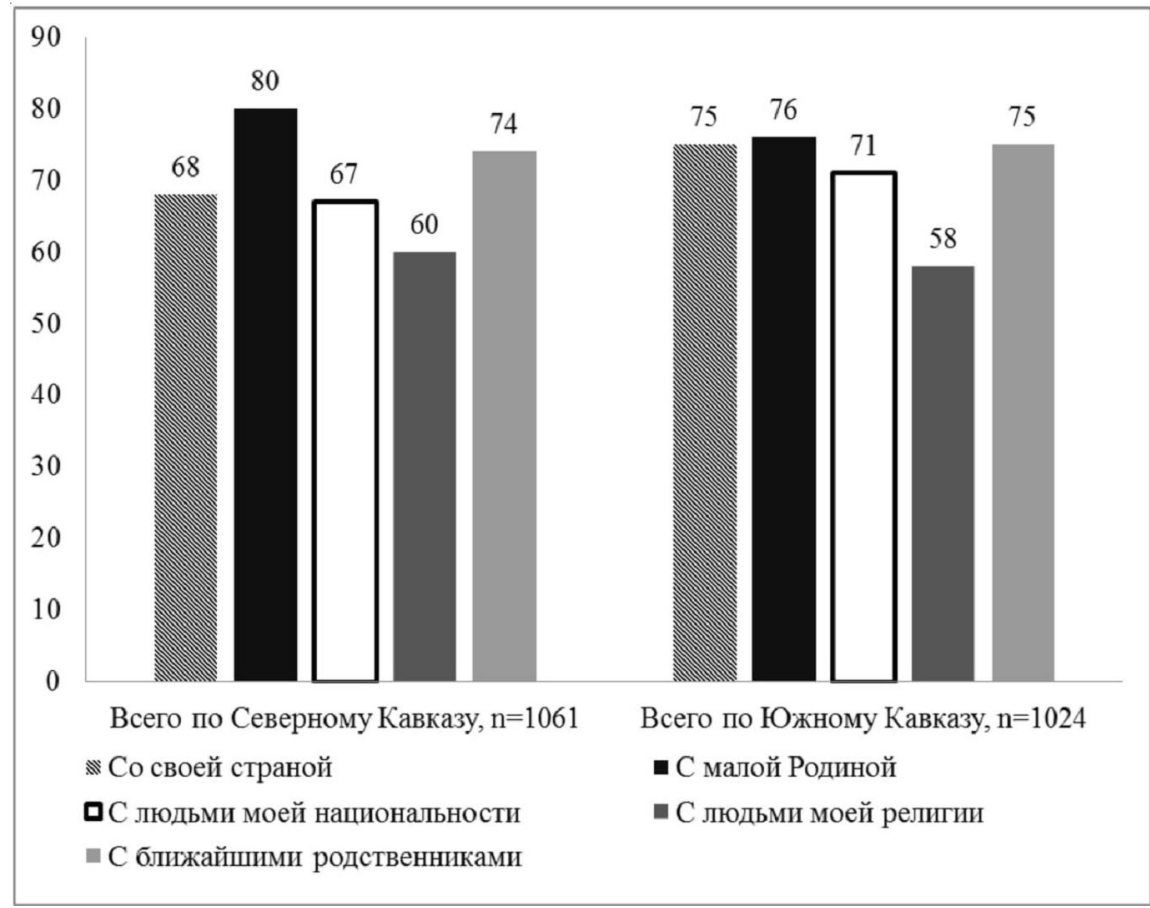

Рис. 3. Насколько важно для Вас осознавать свою связь... (в \%)

Fig. 3. How important is it for you to be aware of your connection... (\%)

Результаты исследования показали, что гражданская и национальная идентичности для абсолютного большинства респондентов Кавказа связаны с сохранением национальной культуры и истории, гордостью за свою страну и ее достижения, защитой Отечества. Можно отметить, что в понимании патриотизма молодежью Кавказа сочетаются как традиционные, так и современные ценности, что может являться фактором их политичес- кой активности. Патриотизм у молодежи Кавказа ассоциируется в первую очередь с сохранением национальной культуры и истории ( $82 \%$ студентов Северного и $87 \%$ студентов Южного Кавказа), с гордостью за свою страну и ее достижения (74 \% - Северного, $78 \%$ - Южного Кавказа) и защитой территориальной целостности и суверенитета страны (73\% - Северного и $71 \%$ - Южного Кавказа), а также с защитой прав и свобод 
(70 \% - студентов Северного и $71 \%$ - Южного Кавказа). Значимых различий во взглядах студентов Северного и Южного Кавказа нет (рис. 4).

Гражданская и политическая активность студенческой молодежи Кавказа. По данным настоящего исследования, студенческая молодежь Кавказского макрорегиона отличается высоким уровнем политической активности и считает для себя важным и значимым участие в общественно-политической жизни страны. При этом она настроена в большей степени на конструктивное решение социально-политических проблем, волонтерскую деятельность, а также диалог и сотрудничество с органами государственной власти. Абсолютное большинство респондентов отметили, что считают необходимым активное участие молодежи в политической жизни своего региона (республики) (77 \% опрошенных на Северном и 84 \% на Южном Кавказе) (см. рис. 5).

Большинство респондентов указало, что хотели бы более активно влиять на политическую ситуацию (см. рис. 6).

Большинство опрошенных считает, что их общественная активность способна оказать влияние на улучшение социально-политической ситуации. Различий во взглядах сту- дентов Северного и Южного Кавказа по этому вопросу нет (см. рис. 7).

Студенческая молодежь Кавказа продемонстрировала высокий уровень готовности участвовать в общественно-политической жизни и вовлеченности в политические процессы. Так, абсолютное большинство респондентов ( $82 \%$ опрошенных на Северном Кавказе и $87 \%$ на Южном Кавказе) готово участвовать в голосовании на выборах. Меньше всего студенты Северного (38 \%) и Южного Кавказа (37\%) хотят посещать митинги и демонстрации. Нет желания большинства опрошенных участвовать в деятельности политических партий, за исключением студентов республики Армения (51 \%). Хотелось бы отметить, что большинство студентов как Северного (60 \%), так и Южного Кавказа (59\%) готовы участвовать в такой форме общественной деятельности, как социальное волонтерство (см. рис. 8).

Ведущую роль в формировании политических взглядов респондентов и на Северном, и на Южном Кавказе играет среда, в которой они общаются, близкие родственники, органы государственной власти, блогосфера и социальные сети, а также ведущие СМИ (см. рис. 9).

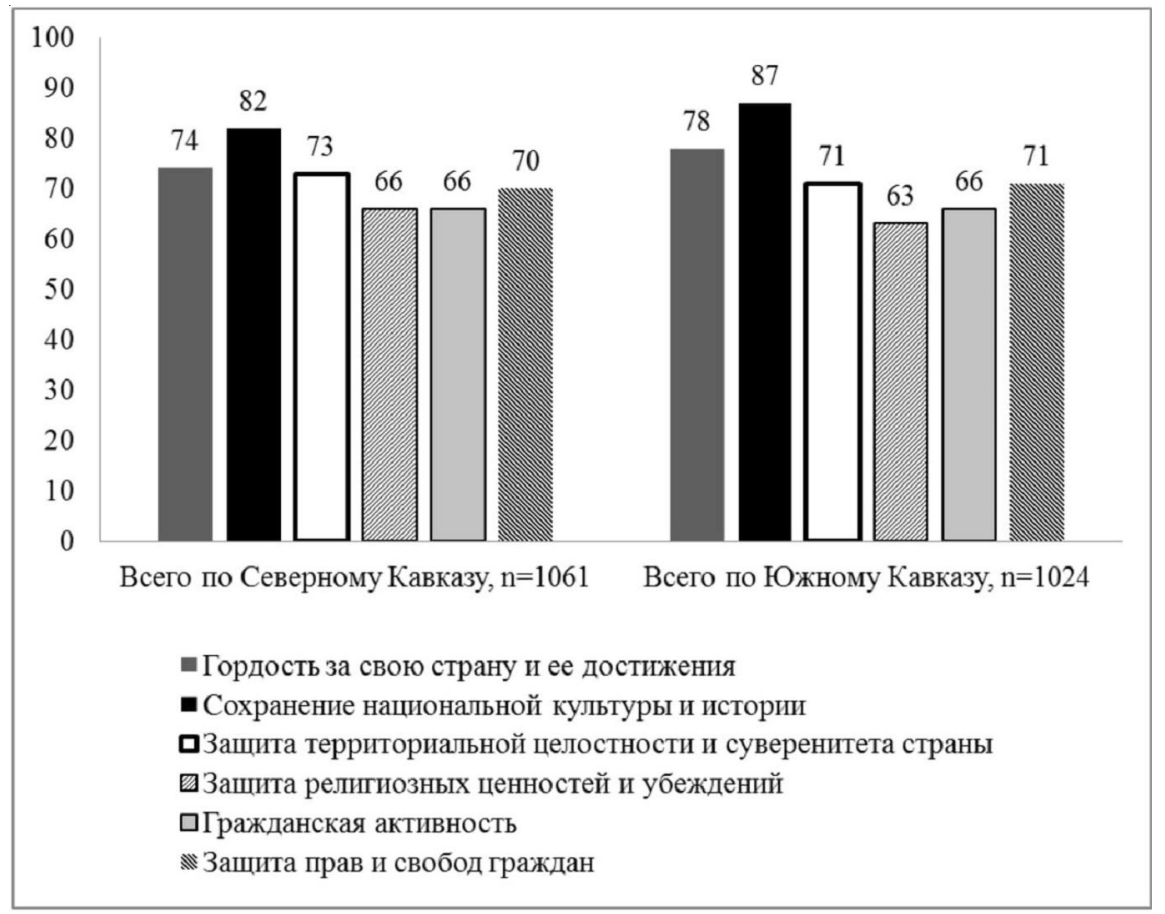

Рис. 4. Что для Вас означает патриотизм? (в \%)

Fig. 4. What does patriotism mean to you? (\%) 
А.М. Ерохин, С.М. Воробьев, Е.А. Авдеев. Этнополитические процессы на Кавказе

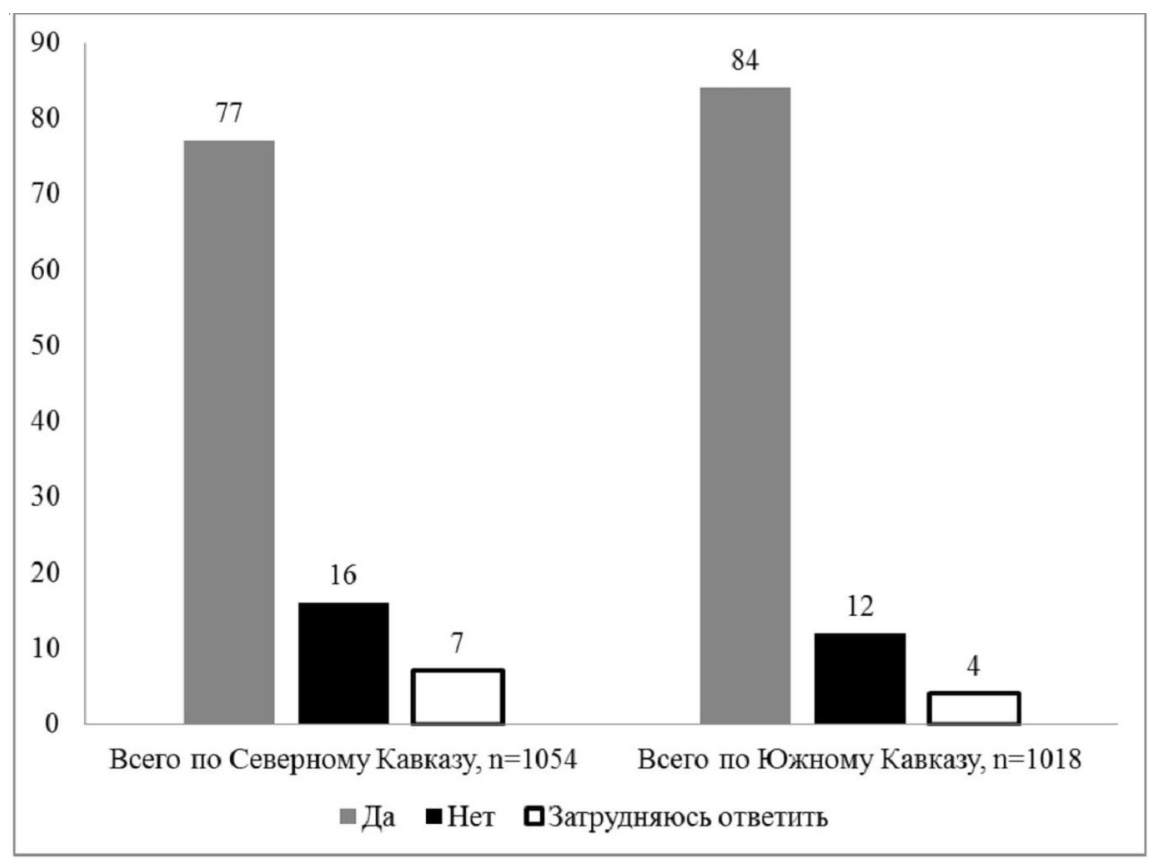

Рис. 5. Считаете ли Вы активное участие молодежи в политической жизни Вашего региона (республики, страны) необходимым? (в \%)

Fig. 5. Do you consider the active participation of youth in political life your region (republic, country) necessary? (\%)

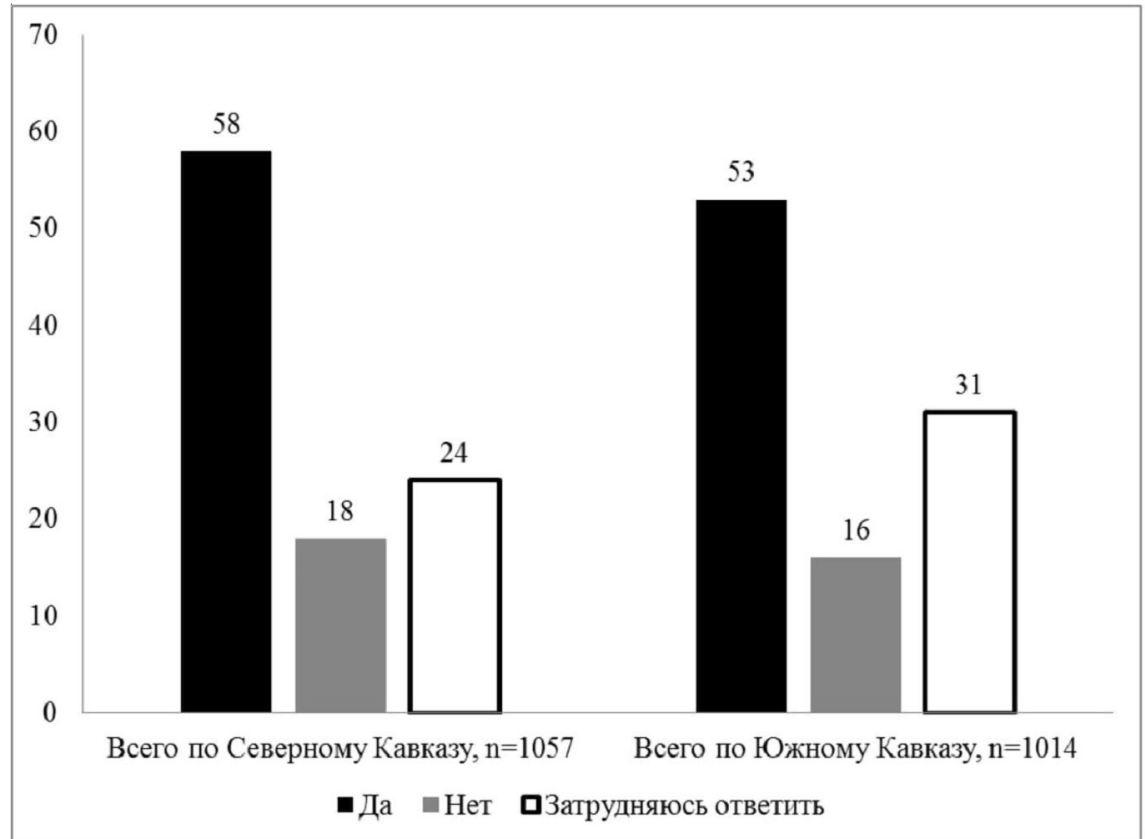

Рис. 6. Хотели ли бы Вы более активно влиять на политическую ситуацию в Вашем регионе (республике, стране)? (в \%)

Fig. 6. Would you like to more actively influence the political situation in your region (republic, country)? (\%) 


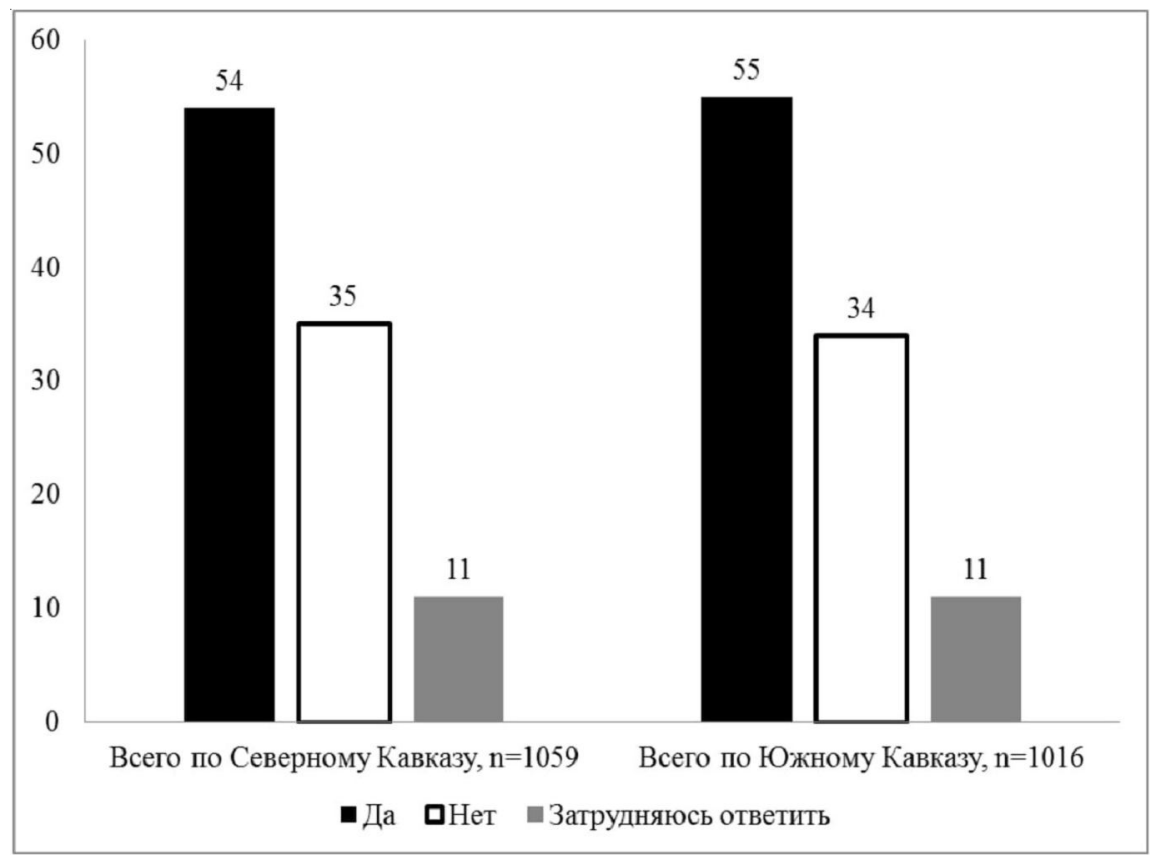

Рис. 7. Считаете и Вы, что Ваша общественная активность повлияет на изменение социально-политической ситуации в Вашем регионе (республике, стране) в лучшую сторону? (в \%) Fig. 7. Do you believe that you, as well as your public activity would have any positive effect on the social and political situation in your area (republic, country)? (\%)

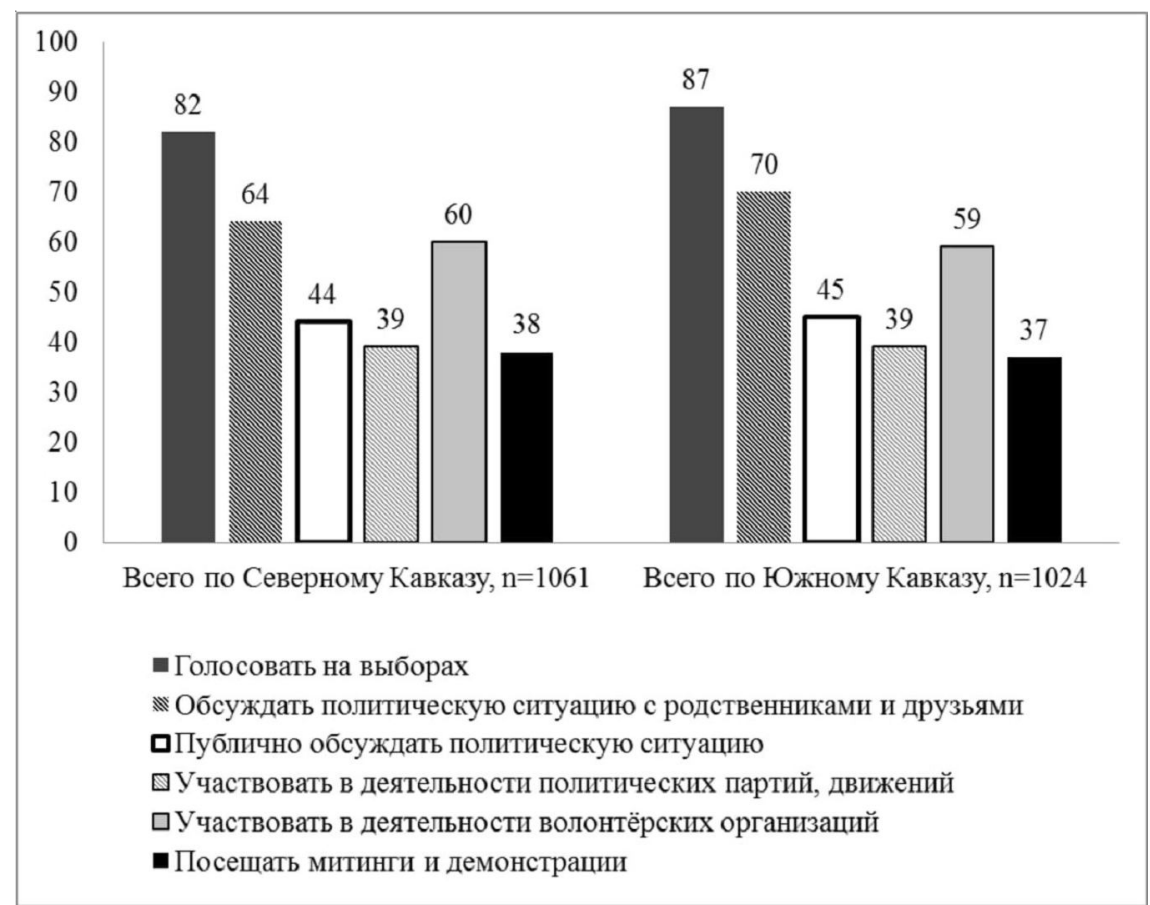

Рис. 8. В каких формах политической активности Вы готовы участвовать? (в \%)

Fig. 8. In what forms of political activity are you ready to participate? (\%) 

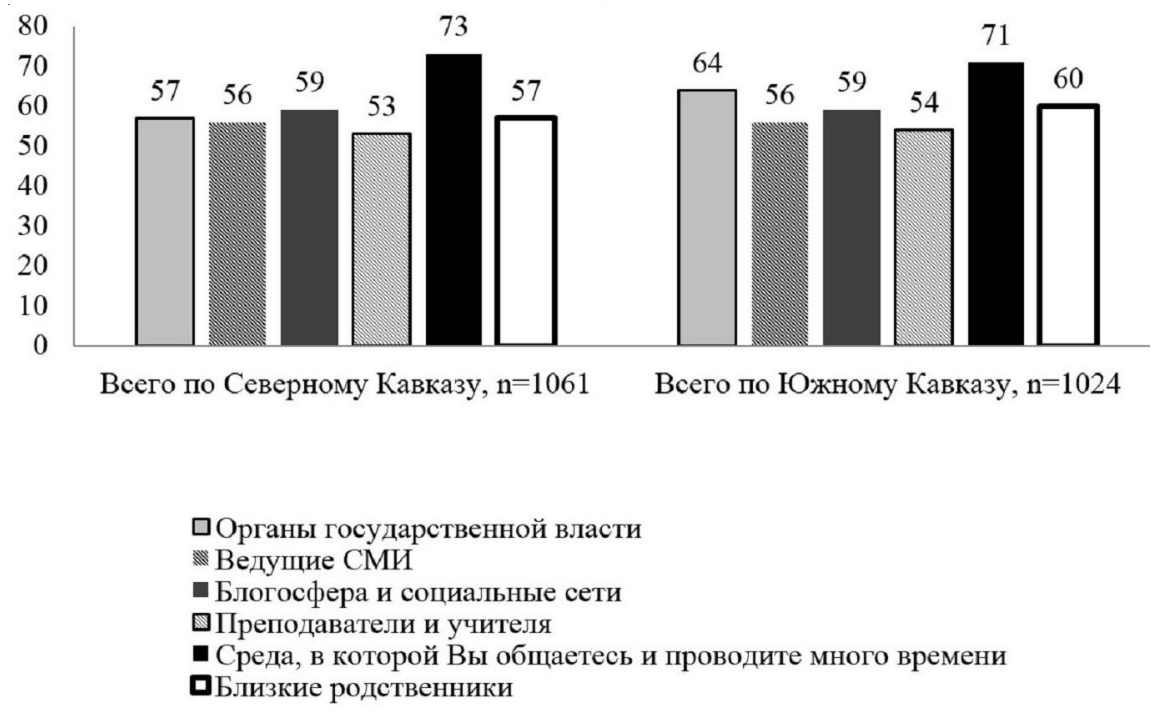

Рис. 9. Кто, по Вашему мнению, повлиял на формирование Ваших политических взглядов? (в \%)

Fig. 9. Who, in your opinion, influenced the formation of your political views? (\%)

Роль органов государственного управления в формировании гражданской и национальной идентичности у молодежи Северного Кавказа. В ходе контент-анализа, проведенного авторами статьи, были проанализированы региональные программы молодежной и национальной политики и другие информационные материалы, отражающие работу органов публичной власти, способствующую формированию межнационального согласия, гражданственности и патриотизма у молодежи региона в 2018 году. Органами публичной власти было проведено около 200 социально значимых мероприятий общественно-политической направленности с привлечением большого числа участников (более 200 тыс. чел.).

Среди них преобладают мероприятия, способствующие формированию межэтнического диалога и согласия, в ходе которых развивалось межэтническое взаимодействие на основе знакомства с национальной культурой и историей народов, проживающих в регионе. Это способствовало развитию этнического самосознания и усиливало этническую идентичность молодежи. Среди наиболее значимых мероприятий меньше тех, которые связаны с формированием патриотизма и гражданственности (см. таблицу). Можно констатировать, что общероссийской гражданской идентичности молодежи Северного Кавказа уделяется меньше внимания.
Это может являться одной из причин конфликтности национальной, религиозной и гражданской идентичностей.

На основе исследования можно сделать вывод о необходимости синхронизации Стратегии государственной национальной политики Российской Федерации на период до 2025 г. и Основ государственной молодежной политики до 2025 года. Следует сформировать единые общие подходы и общее концептуальное видение реализации целей и задач молодежной и национальной политики в субъектах СКФО, включение целей и задач национальной политики в молодежную политику региона. В системе государственного управления субъектов СКФО РФ отсутствует глубокая координация программ национальной и молодежной политики между субъектами СКФО РФ. Необходимо выявление и распространение лучших практик в сфере национальной и молодежной политики во всех субъектах СКФО РФ. Эти предложения могут быть реализованы путем создания единого центра координации и развития молодежной и национальной политики в регионе, что позволит полнее и последовательнее осуществлять курс на формирование общероссийской гражданской идентичности, интеграцию различных этнических и конфессиональных общностей в российское цивилизационное пространство. 


\section{РЕГИОНАЛЬНЫЕ КОНФЛИКТЫ СОВРЕМЕННОСТИ}

Основные мероприятия по формированию межнационального согласия, гражданственности и патриотизма молодежи в субъектах СКФО РФ

The main activities for the formation of interethnic harmony, citizenshipness and patriotism of youth in the subjects of the North Caucasus Federal District of the Russian Federation

\begin{tabular}{|c|c|c|c|c|}
\hline \multirow[b]{2}{*}{ Субъекты СКФО РФ } & \multicolumn{3}{|c|}{ Количество мероприятий } & \multirow[b]{2}{*}{$\begin{array}{c}\text { Всего } \\
\text { мероприятий }\end{array}$} \\
\hline & $\begin{array}{l}\text { Межнациональ- } \\
\text { ное согласие }\end{array}$ & $\begin{array}{c}\text { Гражданствен- } \\
\text { ность }\end{array}$ & $\begin{array}{c}\text { Развитие } \\
\text { общественных } \\
\text { инициатив }\end{array}$ & \\
\hline Ставропольский край & 26 & 19 & 12 & 57 \\
\hline Чеченская Республика & 24 & 18 & 4 & 46 \\
\hline Республика Дагестан & 19 & 13 & 6 & 38 \\
\hline Республика Ингушетия & 7 & 3 & 3 & 13 \\
\hline $\begin{array}{l}\text { Кабардино-Балкарская } \\
\text { Республика }\end{array}$ & 6 & 1 & 1 & 8 \\
\hline $\begin{array}{l}\text { Карачаево-Черкесская } \\
\text { Республика }\end{array}$ & 9 & 4 & 2 & 15 \\
\hline $\begin{array}{l}\text { Республика Северная } \\
\text { Осетия - Алания }\end{array}$ & 2 & 3 & 5 & 10 \\
\hline Всего по СКФО & 93 & 61 & 33 & 187 \\
\hline
\end{tabular}

Продолжение таблицы

Continuation of Table

\begin{tabular}{|c|c|c|c|c|}
\hline \multirow[b]{2}{*}{ Субъекты СКФО РФ } & \multicolumn{3}{|c|}{ Количество участников } & \multirow[b]{2}{*}{$\begin{array}{c}\text { Всего } \\
\text { участников }\end{array}$} \\
\hline & $\begin{array}{l}\text { Межнациональ- } \\
\text { ное согласие }\end{array}$ & $\begin{array}{c}\text { Гражданствен- } \\
\text { ность }\end{array}$ & $\begin{array}{c}\text { Развитие } \\
\text { общественных } \\
\text { инициатив }\end{array}$ & \\
\hline Ставропольский край & 32233 & 29150 & 9223 & 68606 \\
\hline Чеченская Республика & 4650 & 62132 & 520 & 67302 \\
\hline Республика Дагестан & 10580 & 4330 & 1458 & 16368 \\
\hline Республика Ингушетия & 600 & 23000 & 500 & 24100 \\
\hline $\begin{array}{l}\text { Кабардино-Балкарская } \\
\text { Республика }\end{array}$ & 9276 & - & 200 & 9476 \\
\hline $\begin{array}{l}\text { Карачаево-Черкесская } \\
\text { Республика }\end{array}$ & 1410 & 3000 & 320 & 4730 \\
\hline $\begin{array}{l}\text { Республика Северная } \\
\text { Осетия - Алания }\end{array}$ & 90 & - & 600 & 700 \\
\hline Всего по СКФО & 58839 & 121612 & 12821 & 191282 \\
\hline
\end{tabular}

Окончание таблиць

End of Table

\begin{tabular}{|l|c|c|c|c|c|}
\hline \multirow{2}{*}{ Субъекты СКФО РФ } & \multicolumn{5}{|c|}{ Уровень проведения } \\
\cline { 2 - 6 } & $\begin{array}{c}\text { междуна- } \\
\text { родный }\end{array}$ & $\begin{array}{c}\text { федераль- } \\
\text { ный }\end{array}$ & $\begin{array}{c}\text { межрегио- } \\
\text { нальный }\end{array}$ & $\begin{array}{c}\text { региональ- } \\
\text { ный }\end{array}$ & $\begin{array}{c}\text { муници- } \\
\text { пальный }\end{array}$ \\
\hline Ставропольский край & - & 6 & 10 & 24 & 17 \\
\hline Чеченская Республика & 1 & 2 & 13 & 26 & 4 \\
\hline Республика Дагестан & 2 & - & 7 & 22 & 7 \\
\hline Республика Ингушетия & 1 & - & - & 9 & 3 \\
\hline $\begin{array}{l}\text { Кабардино-Балкарская } \\
\text { Республика }\end{array}$ & - & - & 2 & 5 & 1 \\
\hline $\begin{array}{l}\text { Карачаево-Черкесская } \\
\text { Республика }\end{array}$ & - & - & - & 12 & 3 \\
\hline $\begin{array}{l}\text { Республика Северная } \\
\text { Осетия - Алания }\end{array}$ & 1 & - & 3 & 3 & 38 \\
\hline Всего по СКФО & 5 & 8 & 35 & 101 & 3 \\
\hline
\end{tabular}


В сознании молодежи региона снижается роль традиционных духовно-нравственных ценностей и возрастает значение норм и ценностей, сформированных под влиянием блогосферы и социальных сетей. При возрастании роли гражданской идентичности в сознании молодежи, национальная и религиозная идентичности продолжают оставаться значимыми для абсолютного большинства молодых людей Кавказа. Можно констатировать, что среди молодежи региона сохраняются риски конфликтности гражданской, национальной и религиозной идентичностей.

Сформировался запрос молодежи на активное участие в социально-политической жизни региона. Молодежь видит себя субъектом социально-политических процессов, по результатам исследования она в большей степени настроена на конструктивное сотрудничество с региональными органами государственного и муниципального управления. В условиях социокультурных трансформаций, обусловленных процессами модернизации и урбанизации в регионе, сложной экономической ситуации, внешнего идеологического воздействия выход молодого поколения на политическую авансцену может повлечь за собой риски политизации этнической и религиозной идентичностей. Результаты исследования свидетельствуют о значительном влиянии новых медиа - блогосферы и социальных сетей - на формирование социально-политических взглядов молодежи, это актуализирует задачи противодействия распространению негативного контента, формирования позитивной информационной повестки, отвечающей интересам российского государства. Необходимы реализация равноправного партнерства молодежи, институтов гражданского общества и органов государственного и муниципального управления, большее включение молодых людей в деятельность, способствующую экономическому, социально-политическую и культурному развитию региона.

\section{ПРИМЕЧАНИЕ}

${ }^{1}$ Работа выполнена при поддержке гранта Президента Российской Федерации № МК-431.2021.2.

The research was supported by the grant of the President of the Russian Federation No. MK-431.2021.2.

\section{СПИСОК ЛИТЕРАТУРЫ}

1. Авксентьев, В. А. Рискогенные факторы в этнополитической сфере Северного Кавказа / В. А. Авксентьев, Г. Д. Гриценко // Научная мысль Кавказа. 2018. - № 4 (96). - С. 81-91. - DOI: 10.18522/20720181-2018-96-4-81-91.

2. Вебер, М. Хозяйство и общество: очерки понимающей социологии. В 4 т. Т. 2. Общности / М. Вебер. - М. : Высш. шк. экономики, 2017. - 429 с.

3. Дробижева, Л. М. Российская идентичность: дискуссии в политическом пространстве и динамика массового сознания / Л. М. Дробижева // Полис. Политические исследования. - 2018. № 5. - C. 100-115. - DOI: 10.17976/jpps/2018.05.09.

4. Ерохин, А. М. Перспективы теологического образования в поликультурном регионе / А. М. Ерохин, С. Ю. Иванова, А. А. Лагунов // Гуманитарные и социальные науки. - 2018. - № 4. - C. 11-18. - DOI: 10.18522/2070-1403-2018-69-4-11-18.

5. Межэтнические отношения и религиозная ситуация в Северо-Кавказском федеральном округе. Второе полугодие и итоги 2018 г. : эксперт. докл. : науч. моногр. изд. / Р. И. Абакаров [и др.] ; под общ. ред. В. А. Тишкова. - Пятигорск : ПГУ, 2018. - 154 с.

6. Парсонс, Т. Социальная система / Т. Парсонс. - М. : Академ. проект, 2018. - 529 с.

7. Российское общество и вызовы времени / М. К. Горшков [и др.] ; под ред. М. К. Горшкова, В. В. Петухова. - М. : Весь Мир, 2015. - Кн. 1. $336 \mathrm{c}$.

8. Силаев, Н. Ю. «Кавказская специфика»: теоретическое осмысление / Н. Ю. Силаев // Россия и ATP. -2017. - № 4 (98). - С. 31-46.

9. Стародубровская, И. В. Северокавказские города: территория конфликтов / И. В. Стародубровская, К. И. Казенин // Общественные науки и современность. - 2014. - № 6. - С. 70-82.

10. Тишков, В. А. Идентичность и жизненные стратегии студенчества в России / В. А. Тишков, Р. Э. Бараш, В. В. Степанов // Социологические исследования. - 2017. - № 8 (401). - C. 81-87. - DOI: 10.7868/S0132162517080098.

11. Тишков, В. А. Российский народ. История и смысл национального самосознания / В. А. Тишков. - М. : Наука, 2013. - 649 с.

12. Шульга, М. М. Проблемы социокультурной социализации молодежи Северо-Кавказского федерального округа / М. М. Шульга // Теория и практика общественного развития. - 2017. - № 12. C. 10-12. - DOI: 10.24158/tipor.2017.12.1.

13. Этноконфессиональная ситуация в субъектах Российской Федерации Северо-Кавказского федерального округа. Первое полугодие 2018 г. : эксперт. докл. / Р. И. Абакаров [и др.]. - Ставрополь : СКФУ, 2018. - 168 c. 
14. Deutsch, K. Nationalism and Social Communication / K. Deutsch. - Cambridge : The MIT Press, 1966. $-345 \mathrm{p}$.

15. Mann, M. The Sources of Social Power. In 4 vols. Vol. 2. The Rise of Classes and NationStates, 1760-1914 / M. Mann. - Cambridge : Cambridge University Press, 1993. - $824 \mathrm{p}$.

16. Percy-Smith, B. Recognition, Inclusion and Democracy: Learning from Action Research with Young People / B. Percy-Smith, G. McMahon, N. Thomas // Educational Action Research. - 2019. - Vol. 27, iss. 3. P. 347-361.

17. Rothman, J. Resolving Identity-Based Conflict: In Nations, Organizations, and Communities/ J. Rothman. San Francisco : Jossey-Bass Publishers, 1997. - 224 p.

18. Smith, A. The Ethnic Origins of Nations / A. Smith. - Oxford : Basil Blackwell, 1986. - 312 p.

19. Tilly, Ch. The Emergence of Citizenship in France and Elsewhere / Ch. Tilly// International Review of Social History. - 1996. - Vol. 40, iss. 3. - P. 223 236. -DOI: $10.1017 / \mathrm{S} 0020859000113653$.

20. Winter, F. Doing Politics Differently: Middle-Class Youth and Politics in Contemporary Lima / F. Winter // Latin American Perspectives. 2019. - Vol. 46, iss. 5. - P. 73-89.

\section{REFERENCES}

1. Avksentev V.A., Gricenko G.D. Riskogennye faktory v etnopoliticheskoj sfere Severnogo Kavkaza [Risk Factors in the Ethnopolitical Sphere of the North Caucasus]. Nauchnaya mysl' Kavkaza [Scientific Thought of Caucasus], 2018, no. 4 (96), pp. 81-91. DOI: 10.18522/2072-0181-2018-96-4-81-91.

2. Weber M. Hozyajstvo i obshchestvo: ocherki ponimayushchej sociologii. V 4 t. T. 2. Obshchnosti [Economy and Society. Essays on Understanding Sociology. In 4 Vols. Vol. 2. Commonalities]. Moscow, Vysshaya shkola ekonomiki, 2017.429 p.

3. Drobizheva L.M. Rossijskaya identichnost': diskussii v politicheskom prostranstve i dinamika massovogo soznaniya [Russian Identity: Discussions in the Political Space and Dynamics of Mass Consciousness]. Polis. Politicheskie issledovaniya [Polis. Political Studies], 2018, no. 5, pp. 100-115. DOI: 10.17976/jpps/2018.05.09.

4. Erohin A.M., Ivanova S.Y., Lagunov A.A. Perspektivy teologicheskogo obrazovaniya $\mathrm{v}$ polikulturnom regione [Prospects for Theological Education in a Multicultural Region]. Gumanitarnye $i$ sotsial'nye nauki [The Humanities and Social Sciences], 2018, no. 4, pp. 11-18. DOI: 10.18522/20701403-2018-69-4-11-18.

5. Abakarov R.I. et al. Mezhjetnicheskie otnoshenija i religioznaja situacija $v$ Severo-
Kavkazskom federalnom okruge. Vtoroe polugodie $i$ itogi 2018 g.: ekspert. dokl. : nauch. monogr. izd. [Interethnic Relations and Religious Situation in the North Caucasus Federal District. The Second Half and the Results of 2018. Expert Report]. Pyatigorsk, PGU, 2018. 154 p.

6. Parsons T. Socialnaja sistema [The Social System]. Moscow, Akademicheskij proekt Publ., 2018. 529 p.

7. Gorshkov M.K. et al. Rossijskoe obshchestvo $i$ vyzovy vremeni [Russian Society and the Challenges of Time]. Moscow, Ves' Mir Publ., 2015, book 1. 336 p.

8. Silaev N.Ju. «Kavkazskaja specifika»: teoreticheskoe osmyslenie ["The North Caucasus peculiarities": An Attempt to Theorize]. Rossiya i ATR [Russia and the Pacific], 2017, no. 4 (98), pp. 31-46.

9. Starodubrovskaja I.V., Kazenin K.I. Severokavkazskie goroda: territorija konfliktov [North Caucasian City: Territory of Conflicts]. $\mathrm{Ob}$ shchestvennye nauki i sovremennost' [Social Sciences and Contemporary World], 2014, no. 6, pp. 70-82.

10. Tishkov V.A., Barash R.E., Stepanov V.V. Identichnost i zhiznennye strategii studenchestva $\mathrm{V}$ Rossii [Identity and Students' Vital Strategies in Russia]. Sotsiologicheskie issledovaniya [Sociological Studies], 2017, no. 8 (401), pp. 81-87. DOI: 10.7868/S0132162517080098.

11. Tishkov V.A. Rossijskij narod. Istorija i smysl nacionalnogo samosoznanija [Russian People. The History and Meaning of National Identity]. Moscow, Nauka Publ., 2013. 649 p.

12. Shulga M.M. Problemy sociokulturnoj socializacii molodezhi Severo-Kavkazskogo federalnogo okruga [Problems of the Youth Sociocultural Socialization in the North Caucasus Federal District]. Teoriya i praktika obshchestvennogo razvitiya [Theory and Practice of Social Development], 2017, no. 12 , pp. 10-12. DOI: 10.24158/tipor.2017.12.1.

13. Abakarov R.I. et al. Etnokonfessionalnaya situaciya v subyektah Rossijskoj Federacii SeveroKavkazskogo federalnogo okruga. Pervoe polugodie 2018 g.: ekspert. dokl. [Ethnic and Confessional Situation in the Entities of the Russian Federation of the North Caucasus Federal District. First Half of 2018. Expert Report]. Stavropol, SKFU, 2018. 168 p.

14. Deutsch K. Nationalism and Social Communication. Cambridge, The MIT Press, 1966. $345 \mathrm{p}$.

15. Mann M. The Sources of Social Power. In 4 Vols. Vol. 2. The Rise of Classes and NationStates, 1760-1914. Cambridge, Cambridge University Press, $1993.824 \mathrm{p}$.

16. Percy-Smith B., McMahon G., Thomas N. Recognition, Inclusion and Democracy: Learning from 
Action Research with Young People. Educational Action Research, 2019, vol. 27, iss. 3, pp. 347-361.

17. Rothman J. Resolving Identity-Based Conflict: In Nations, Organizations, and Communities. San Francisco, Jossey-Bass Publishers, 1997. 224 p.

18. Smith A. The Ethnic Origins of Nations. Oxford, Basil Blackwell, 1986.312 p.
19. Tilly Ch. The Emergence of Citizenship in France and Elsewhere. International Review of Social History, 1996, vol. 40, iss. 3, pp. 223-236. DOI: 10.1017/ S0020859000113653.

20. Winter F. Doing Politics Differently: MiddleClass Youth and Politics in Contemporary Lima. Latin American Perspectives, 2019, vol. 46, iss. 5, pp. 73-89.

\section{Information About the Authors}

Aleksej M. Erohin, Doctor of Sciences (Sociology), Professor, Head of the Department of Philosophy, North-Caucasus Federal University, Pushkina St, 1, 355017 Stavropol, Russian Federation, a_erohin@mail.ru, https://orcid.org/0000-0002-8315-3250

Sergej M. Vorobev, Candidate of Sciences (Politics), Associate Professor, Department of Philosophy, North-Caucasus Federal University, Pushkina St, 1, 355017 Stavropol, Russian Federation, sergey_vorobev_54@mail.ru, https://orcid.org/0000-0002-8893-2595

Evgenii A. Avdeev, Candidate of Sciences (Philosophy), Associate Professor, Department of Philosophy, North-Caucasus Federal University, Pushkina St, 1, 355017 Stavropol, Russian Federation, ewg.avdeev@yandex.ru, https://orcid.org/0000-0003-4004-9610

\section{Информация об авторах}

Алексей Михайлович Ерохин, доктор социологических наук, профессор, заведующий кафедрой философии, Северо-Кавказский федеральный университет, ул. Пушкина, 1, 355017 г. Ставрополь, Российская Федерация, a_erohin@mail.ru, https://orcid.org/0000-0002-8315-3250

Сергей Михайлович Воробьев, кандидат политических наук, доцент кафедры философии, Северо-Кавказский федеральный университет, ул. Пушкина, 1, 355017 г. Ставрополь, Российская Федерация, sergey_vorobev_54@mail.ru, https://orcid.org/0000-0002-8893-2595

Евгений Александрович Авдеев, кандидат философских наук, доцент кафедры философии, Северо-Кавказский федеральный университет, ул. Пушкина, 1, 355017 г. Ставрополь, Российская Федерация, ewg.avdeev@yandex.ru, https://orcid.org/0000-0003-4004-9610 